\title{
Home, Militarism and Nostalgia in Japanese Popular Song from 1937 to 1945
}

\author{
Sabiene Strasser
}

\begin{abstract}
The article focuses on the representation of wartime Japan as a home (and home country) by analysing contemporary popular songs. Within this frame I show examples of how the Japanese state managed to influence the Japanese people through propaganda songs in order to gain the people's moral support for the war effort. My essay aims further at drawing a picture of Japan's musical world from the latter half of the 1930s to the end of World War II, as a detailed consideration of popular music and its surroundings always allows us to interpret much more than expected at first view.

In addition, I consider the mass media as a supporter of Japan's ideological aims. The history of radio and record companies is firmly interwoven with the efforts of the Japanese state to manipulate people during the war years. The contribution from artists must also be considered an important part of this mosaic.
\end{abstract}

Keywords: general mobilisation, gunka kayo, Japanese popular song, propaganda in Japan, Second Sino-Japanese War

Strasser, Sabiene. "Home, Militarism and Nostalgia in Japanese Popular Song from 1937 to 1945." In Vienna Graduate Journal of East Asian Studies, Volume 2, eds. Rudiger Frank, Ingrid Getreuer-Kargl, Lukas Pokorny and Agnes Schick-Chen. Vienna: Praesens Verlag, 2011, pp. 115-147.

https://doi.org/10.2478/vjeas-2011-0011 


\section{Introduction}

According to a popular German saying, 'evil people have no songs'. 'If so, why would popular songs then be a perfect medium to affect people in a doubtful way? Are popular songs only for light entertainment, with seemingly irrelevant lyrics? Is there nothing more to listen and look at?

My initial interest in Japanese popular song was aimed at the description and representation of Japan as a home and a home country in wartime song lyrics. Popular songs produced during wartime, a time of crisis and often of the loss of home, seemed to offer a rich yield of lyrics regarding 'home'.

When I noticed there were two kinds of songs to distinguish-propaganda war songs and nostalgic songs, my main interest focused on the differences in the representation of Japan within the songs. Understanding that, besides different kinds of propaganda, e.g. propaganda movies, popular song was an important propaganda tool, I began to search for sources that would help me to unwrap a dark chapter of Japanese music history. I realised that this topic would not only be about images of 'home' in popular song, but also about the 'teamwork' of the Japanese wartime government, radio stations, newspapers and songwriters. Reading and understanding lyrics of popular songs can never be done without considering contemporary circumstances and thus can never be described without an explanation of what lies between the lines.

My research began with the questions: "How was wartime made "audible" in popular music?' and 'How was Japan constructed and represented as a home in wartime popular song?', and ended with the question of the responsibility of artists, producers and distributors and how the Japanese public deals with these songs today. I investigated the years from 1937 to 1945, beginning with the Second SinoJapanese War (7 July 1937), which led to Japan's entry into World War II (7 December 1941). ${ }^{2}$ This period of time can be easily divided into two parts of equal length: the first four years until 1941 were a successful period for Japan, whereas from the beginning of the second period until 1945 a signal defeat loomed.

In this article I give a summary of my research results, starting with a short historical introduction on how propaganda was established in Japan. I explain the propaganda network, its supporters and producers as well as the political premises for the development of the plans for a general mobilisation, including the commissioning of songs. Giving examples for frequently used symbols and metaphors, I will show how lyrics can be 'unwrapped'. Concluding the article, I introduce further

1 'Wo man singt, da lass' dich ruhig nieder, böse Menschen haben keine Lieder', Johann Gottfried Seume (1763-1810). Througout this essay, phrases not expressly marked as translated by others have been translated by myself.

2 This period also corresponds to the 'Pacific War'. 
questions for continuing research on Japanese propaganda in the entertainment industry.

\section{Mental propaganda in Japan}

\section{Emotional propaganda and its aims}

In questioning how to make a nation willing to give mental support to war, we have to look at how war and its demands towards civilians have changed over time. According to Marcel van der Linden and Gottfried Mergner (Linden and Mergner 1991: 12-14), trends regarding war fever can be separated into three major stages:

1. The pre-modern stage until about 1700 , when wars were carried out by small professional armies, and the rest of the people were victims but not participants

2. The second stage until 1945, when larger sections of the population were involved, either actively fighting or working in the war industry. In this stage the population's interest in war rose-losing a war was not only about losing territory but also about the loss of national honour. War furthermore became a battle of economic competences, requiring industrial mobilisation

3. The third stage is the stage of nuclear and sub-nuclear wars, carried out by small groups of specialists mainly in third world countries

In the pre-nuclear stage, when the approval of the population was necessary, propaganda was conducted by the elite and supported through censorship and suppression of resistance. This, and general resignation, would lead to an image of a broad civilian population who agreed with the aims of the war-makers. The denial of death and misery and the image of war as an adventure were used to motivate the combatants - as propaganda has to correspond to each target group in a different way. As a consequence, the means of propaganda vary: radio broadcasting, art, newspapers and pamphlets were used to mislead the enemy, encourage combatants and boost morale on the homefront.

Mass propaganda emerged first in World War I, and its means developed during the interwar period through technical advances. To reach the vast majority of people in their daily lives, the mass media were considered a perfect channel.

In terms of psychological warfare, Ortwin Buchbender and Horst Schuh (Buchbender and Schuh 1983: 13) discern strategic and tactical propaganda. Whereas the former is a long-term matter, the latter is required to adapt to actual incidents. Regarding the sources of production of propaganda, Buchbender and 
Schuh use colours to explain: 'white' propaganda reveals its sources, and names the commissioning agent; 'grey' propaganda has no classifiable emitter; and 'black' propaganda conceals its commissioning agent and producers.

The songs considered for this thesis functioned as white propaganda, they were commissioned by a ministry or a publishing company, and the composers and authors often were household names in the Japanese music industry.

Popular songs are an amazingly helpful source for emotional propaganda: the language in the songs influences people where it implies a good feeling and familiarity. One tends to believe what is sung, if there is a possibility to identify with itthis can happen through the mention of familiar names and places, or pictorial descriptions of these. If the emitter is a person or an institution with an established reputation, it is very likely that the vast majority would not consider asking what lies between the lines of a popular song, especially in times of crisis, when everybody has to struggle to think rationally. Michael Balfour cites Immanuel Kant: 'die Notwendigkeit zu entscheiden reicht weiter als die Möglichkeit zu erkennen' ['the need to make up one's mind has to take priority over one's ability to analyse the facts'] (Balfour 1979: 422). This is the point where emotional propaganda can have an effect, while producing and strengthening feelings like patriotism, national pride and hatred of enemies. These are the feelings that can make people agree to war and legitimate it, a process that becomes achievable through the fielding of the mass media (see Balfour 1979: 420-425).

\section{'Imperial propaganda' and 'ideological warfare' (shisōsen)}

In comparison to Germany, where war propaganda was pursued, the term 'imperial propaganda' is used when speaking of Japanese propaganda of that time. 'Imperial' is not a literal reference to the Japanese emperor in person but refers to Japan's selfimage as a nation, representing a leading position in East Asia after having beaten China (1895) and Russia (1905). The Japanese government learned that efficient propaganda should never only 'come down from above', but also from the middle. Moreover, propaganda could also be carried out by the people themselves, so why not incorporate everyone? Public competitions were the result, in which anybody could submit war songs and marches.

Another difference to Germany lies in the fact that Japan had no particular ministry for propaganda and therefore no such person as Joseph Goebbels. There was no equivalent to the National Socialist German Workers' Party and no Führer; unlike in Germany, Italy or Russia, there was no proper base for a personality cult.

There was less actual advertising for the Japanese emperor as a descendant of the mythic sun goddess, Amaterasu, than for a modern Japanese state that would bring advantages for everybody (Kushner 2006: 10-11). Fundamentally, at the beginning 
of the war every ministry was able to take propaganda measures, a situation that often led to confusion at the front. Intellectuals, unlike intellectuals in Germany, stayed in the country and invested time and money in the war. Most of them were imperialists. Until the attack on Pearl Harbor in 1941, Japanese propaganda had not been well organised - in fact, censorship and manipulation through news were the main tools to influence the Japanese people. By establishing a new, exclusive news agency (see also the section below on the Press and Information Agency), reducing the numbers of newspapers and magazines and operating strict police censorship, 'dangerous thoughts' could be easily controlled and suppressed (Tipton 2002: 127128).

The term shisōsen 思想戦 (ideological warfare) arises in publications around the period after the Mukden Incident (1931). Japan's goals - supremacy in Asia and in the battle against the West, against democracy and individualism-needed to be accepted by the Japanese. In Japanese perception, only a modern state such as Japan could lead Asia through the 20th century and free Asia from Western colonial rule. Barak Kushner sees three reasons for the success of Japanese propaganda, which in the event proved sustainable:

1. The production of propaganda was not limited to military or fascist circles, but also incorporated writers, photographers, bureaucrats and advertisers. Today we may assume that the general public believed in Japan's mission.

2. Propaganda came into people's daily lives through the mass media, and was reproduced in multiplying quantities.

3. None of the participating institutions took the success of measures for granted. The police and the military conducted surveys and studies to ensure a continuous adaptation to popular opinion (Kushner 2006: 15-16).

Despite good technical equipment, Japan assumed that its first successful battles resulted from courage, ingenuity and a spiritual superiority. They even characterised their American opponents thus: '...how much poorer are they in spiritual power compared to Japan!' (Shillony 1981: 134). The spiritual energy of the Japanese nation was based on the power of the kami 神 (deities), which consisted of deceased emperors and soldiers, and ancestors who would support their descendants in their plans and actions for war. This persuasion and its combination with science and techniques (even as these were viewed as materialistic products of the West) were responsible for the initial achievements of the Japanese military. 
The installation of the Press and Information Agency and its support to propaganda

In early 1935, a research team suggested the founding of a propaganda co-ordinating agency, to distribute unified messages to the public. This institution was to be subordinated to the prime minister and work on planning propaganda measures, analysis of international and domestic propaganda and research on ideological warfare (Kido Nikki Kenkyūkai (ed.): Kido kōchi kankei monjo. Tōkyō: Daigaku Shuppankai, 1966: 186; cited in Kushner 2006: 26). In September 1937, the cabinet information office (naikaku jōhō-bu 内閣情報部) was established, an unofficial post where volunteers co-ordinated propaganda strategies between several ministries and offices. By the end of the 1930s, the information office also took over the responsibility for propaganda abroad, which before had been a task of the Ministry of Foreign Affairs. In 1940, the cabinet information office was upgraded and renamed the Press and Information Agency (PIA) (Jōhō-Kyoku 情報局). Its defined tasks were cultural control and censorship and the agency grew to be the 'general staff of ideological warfare’ (shisōsen no sanbō honbu 思想戦の参謀本部) (Kitagawa 1989: 44). The day after Japan's entry into World War II on 8 December 1941, the PIA decided on a ban on two kinds of newspaper reports: firstly, those expressing opinions against the military or the government, and secondly, reports with contentious content and/or expressing tendencies against war and for peace. The co-operation of newspapers and magazines played an important role, which also showed in the commissioning of war and propaganda songs, as I will describe later.

\section{State Shintō}

Ernst Lokowandt sees state Shintō (kokka shintō 国家神道) as indirect ideological support for the irresponsible military government (Lokowandt 1981: 4-5). State Shintō, despite its name, has hardly anything in common with the original concept of Shintōism. State Shintō rose around 1905 and was adapted as a non-religious state ideology. Adaptions included the systematisation and centralisation of shrines and the worship of ancestors, who became equivalent to deities. The family, moreover, was considered as the fundamental national entity. A mandatory ideology for all citizens was developed, in which appreciation was shifted from physical nature to social characteristics.

The most important function of state Shintō, though, was to legitimise the status of the Japanese imperial court and to cement the myth of the Tennō 天皇, positioned above parliament, the government, the court and the constitution. Since the Tennō rarely took decisions, the government was only responsible to itself, and the military too was unofficially independent. In the ideology of the 'family state', which devel- 
oped at the end of the 19th century, the imperial family was seen as the 'main family' and the Japanese people as the 'branch family'. This ideology strengthened solidarity and the team spirit within the Japanese nation and became a basis for Japanese nationalism, a development that brought suppression of other religious beliefs (Buddhism, Christianity) and the exclusion of dissidents. The term 'Gleichschaltung' can be applied to state Shintō, which was a fundament for ethics and education and a pillar for the Japanese nation that led Japan into the war.

\section{Into war-mobilising the people mentally}

The date 7 July 1937 marks the beginning of the Second Sino-Japanese War. The circumstances of the incident at the Marco Polo Bridge, when a gunfight opened between Japanese and Chinese soldiers, have still not been clearly explored. Even though a truce was declared, Prime Minister Prince Konoe Fumimaro 近衞文麿 sent five divisions to China, without an official declaration of war. Shànghăi fell on 12 November and Nanjing was captured one month later, an event we today call the Nanjing Massacre. At that time, the Japanese public was still made to think that these incidents were nothing more than individual happenings, not signs of a longstanding war.

Earlier, after the Mukden Incident in 1931, the Cabinet had begun to realise it had to mobilise civilians if it was to get through a war. Censorship and the purge of anything Western in daily life, alongside the belief in the mythic history of Japan and the divinity of the emperor delivered a perfect justification for Japan's mission (Hall 1968: 336).

On 24 August 1937, the Konoe Cabinet decided on a programme of 'mental mobilisation' (seishin sōdōin 精神総動員), using the slogans 'national entity' (kyokoku itchi 挙国一致) and 'violent castigation of China' (bōshi yōchō 暴支膺懲). Further slogans were 'serve the home country faithfully' (jinchū hōkoku 尽忠報国) and 'persistent perseverance' (kennin jikyū 賢忍持久). In October 1937, the 'Central Alliance for the mental mobilisation of the people' (Kokumin Seishin Sōdōin Chūōrenmei 国民精神総動員中央連盟) was established, a tight network of local groups to engage in propaganda events (Kitagawa 1989: 8-9). With the ongoing battles, censorship, propaganda, and instructions regarding 'economic consumption', the government tried to prepare civilians for total war (Brown 1955: 211; Kitagawa 1989: 9-10). 


\section{The National Law of General Mobilisation}

The National Law of General Mobilisation (Kokka Sōdōin Hō 国家総動員法) was passed in March 1938 and marked the beginning of a new period. Not only economic sectors but also social and cultural affairs were affected, as I explain in the following sections. According to the new law, which became effective in May 1938, Prime Minister Konoe would obtain quasi-'total power', and the government was about to separate from parliament. This led to turmoil within parliament, especially among the mainstream parties, but through the pressure of the military it was possible to pass the law.

Besides economic matters, ${ }^{3}$ all fields of daily life were subject to the National Law of General Mobilisation. A manual, 'Principles of the Body Politic' (Kokutai no hongi 国体の本義), was published by the Ministry of Education and Cultural Affairs to stress the unique character and spirit of the Japanese nation; the myth of the imperial court and the duty of loyalty were taught in schools.

As voices ${ }^{4}$ for a united party and a reorganisation of the government became louder, the Imperial Rule Assistance Association (IRAA) (Taisei-Yokusan-Undō 大政翼賛運動), modelled on the German NSDAP (The National Socialist German Workers' Party), was founded on 12 October 1940. Kushner explains the founding of the IRAA as a reaction to a campaign for mental mobilisation in August 1937 that had failed to meet the expected results (Kushner 2006: 28). Konoe, who had been partyless before, took office the second time on 22 July 1940 and became the leader of the IRAA. The other parties were forced to dissolve.

Though the IRAA was modelled on the NSDAP, dictatorship was never sought and fascism never became a public creed, but there was strong nationalism and ethnocentrism. But no shifting of capital was planned, and there was no Führer (Zöllner 2006: 376). Delmer M. Brown describes the IRAA as another powerful instrument for carrying out the mobilisation of the Japanese spirit, with none of the characteristics of a political party; Konoe himself saw the IRAA as a 'movement to make clear, what kokutai 国体 is' (Brown 1955: 221). To be able to distribute propaganda effectively, the IRAA used sociological and statistical means, and its surveys, conducted all over the country, showed that most people had not understood the meanings of the propaganda slogans so far. To the IRAA, this meant that other means had to be used to convince people, such as entertainment, music and sports.

3 Expenses for armaments and the arms industry increased, and investment in the consumer goods industry and imports was reduced. Women and children, as 'human material' (ninteki shigen 人的資源), were 'integrated' into the arms industry (Tamura 2006: 1-2).

4 The 'New National Organization' (Shintaisei 新体制) movement was formed to initiate a new structure for the government. 


\section{Mental mobilisation and the 'cultural aspect'}

The IRAA contained a cultural department, responsible for musical affairs. From 1939, musicians and singers had needed a licence to work. When the government sought the mobilisation of professional musicians and composers, preparations for a new organisation were made under the supervision of the Ministry for Education and Cultural Affairs. The Cultural Union for Japanese Music (Nihon Ongaku Bunka Kyōkai 日本音楽文化協会) was instituted on 29 November 1941 (Sakuramoto 2005: 145; Sasaki 1976: 168), with the aim of mobilising people involved in musical affairs for war purposes. Members consisted of composers and musicians, music critics and music teachers.

As the war continued, resources such as paper became scarce. This was presented as a good reason to justify the inspection of newspapers and magazines regarding their 'qualification'. Many magazines ceased, and by 1941 the number of music magazines was limited to twenty (Sasaki 1976: 169). At that time, Japan's musical world was monopolised by war propaganda. Of course, the musical education of children was also brought into service for the war; many children's songs of that period give an idea of how children were ideologically educated, though many of the titles are subtle: 'Thank you, Mr Soldier' (1939, 'Heitaisan yo arigatō' 兵隊さんよ ありがとう), 'Rice plantling' ('Taue' 田植, 1942) or 'Daddy, you were strong' ('Chichi yo anata wa tsuyokatta'父よあなたは強かった, 1938).

\section{The Second Sino-Japanese War and its impact on radio programmes and popular music}

\section{Radio as a supporting means for state propaganda}

Japanese radio producers were aware that music was an effective medium to touch people's feelings - with the initial war successes radio programming 'flourished' too. As a side effect, after 8 December 1941, foreign music became strictly forbidden on Japanese radio, a consequence after years of control of the radio channel concerning 'proper' music (Takeyama 2005: 127).

The first radio broadcasts were aired in 1925 from broadcast senders in Tōkyō, Ōsaka and Nagoya. The Japanese Broadcasting Corporation NHK (Nihon Hōsō Kyōkai 日本放送協会) was established in 1926, and preserved its monopoly until 1951 (Yano 2002: 35). As early as summer 1937, in particular after the Mukden Incident on 18 September 1931, the ministries had discovered radio broadcasting as an important strategic means to spread the 'Japanese spirit'. In 1934, the autonomy of NHK branches was rescinded, and centralisation was initiated. This so-called 
reform was presented to directors and investors in spring 1934 by Tamura Kenjirō (Kasza 1988: 153-154). Part of his plan called for ex-bureaucrats to assume highranking positions, and a 'planning council' that would rule more than 80 percent of the programme. Alongside this reform, the Ministry for Foreign Affairs and Communication founded a new press agency in 1935, the Dōmei Tsūshinsha 同盟通信社, which from then on was to exclusively deliver news to the NHK. The new-founded agency was supported not only with NHK money, but also with personnel. Other agencies which had been suppliers to NHK-like Rengō 連合 and Dentsū 電通— became superfluous, while NHK and its 'house agency' created the radio programme together (Kasza 1988: 156-157). Autonomous sources were completely wiped out. From 1941 on, there were more and more incidents that were worth being broadcast, radio became the mouthpiece of the military, and as the war progressed, an increase in war fever became a specific goal. Kobyashi Tokujirō, head of the entertainment and the music section in the Department of Labour, saw entertainment as something 'that had to be sound and cheerful. Further, it [entertainment] must raise eagerness. Down to the smallest item, it has to turn into the capital of tomorrow's activities' (Takeyama 2005: 154).

Since theatres, revues and similar entertainment facilities were restricted, the radio played a major role as a medium that would immediately catch the actual mood and respond to it. Gordon Daniels tells us that 'patriotic excesses' were cut short in the last year of the war in favour of indirectly patriotic contents, such as Japanese art and Zen Buddhism (Daniels 1998: 277). Besides entertainment, another reason for turning on the radio was its role as an information tool, especially when warningse.g. of air raids - were issued.

Technical and scientific achievements from the West were useful for fighting a war and could not have been avoided easily, so the avoiding and restricting was shifted to another 'harmless' field: culture and entertainment. One of the first steps in this direction was the broadcasting of a radio show called Kokumin Kayō 国民歌 謡 ('National songs') in 1936 in Ōsaka, to help in the purge of Western influences from the channel. Later, in 1942, the show was renamed Kokumin Gasshō 国民合唱 ('Folk choir'). Sakuramoto Tomio 桜本富雄 assumes that the campaign Nihon Kokuminka Undō 日本国民歌運動 ('Japanese folksongs') was sponsored by the Ministry for Culture and Education for the same reason (Sakuramoto 2005: 30-31). Songs that had been featured on the radio show were later published in a weekly publication to enable listeners to sing the songs themselves (Takeyama 2005: 127; Sakuramoto 2005: 75-84). From January 1942, the elimination of 'enemy music' (tekisei ongaku 適性音楽) became a slogan, using the phrase 'increase in national fighting spirit' (kokumin no sen'i kōyō 国民の戦意高揚). While music from Germany and Italy was tolerated, American and British music was strictly withdrawn, not only modern music like jazz, but also classical compositions and 'serious' music. In addition, the German embassy successfully raised objections over co- 
operation between Japanese and Jewish musicians (Choki 2003: 8; Sasaki 1976: 172-173). Furthermore, Japanese music pieces were not supposed to be arranged in a 'foreign' style, using Western instruments like the banjo, the ukulele or simply guitars, and in 1943 the PIA published a list of 1,000 songs that had to be banned from the radio. The results of these bans were only too natural: after years of enthusiasm for the United States and its lifestyle, it was now hard to abandon modern American music, and so jazz was played secretly in certain bars. From the official side, traditional Japanese music was promoted as a counterpart to Western music: pieces with arrangements for shakuhachi 尺八, koto 琴 and shamisen 三味線, and the so-called national music (kokumin ongaku 国民音楽), which was considered as 'healthy music'. Especially in 1940, when the 2600th anniversary of the mythical founding of the Japanese state was celebrated, the general atmosphere was pushed to become loaded with spiritual strength.

Not only was the radio channel censored, but records were inspected, and even 'rekōdo'レコード (modern Japanese for 'record') turned to 'onban' 音盤 (literally 'sound disc') to avoid any American influence on words associated with music (Komota et al 1981: 112).

But censorship was not finished yet, as Japanese songs with nostalgic lyrics were stopped by the authorities, though they often spread very quickly. Well-known examples were 'Border town' ('Kokkyō no machi' 国境の町, 1934) and 'Shelter by the lakefront' ('Kōhan no yado’ 湖畔の宿, 1940). Through gunka kayō 軍歌歌謡, the heroic actions of the Japanese military were to be brought to the people in a simple language.

\section{Commissioning war songs}

In 1927 there were three major record labels in Japan: Nippon Columbia, Nippon Victor and Nippon Polydor. These were branches of the American and British Columbia, the American Victor and the German Polydor, established with foreign capital. Until that time, it had been the usual practice to record songs after they turned out to be popular 'outside'. But from then on, record labels started to produce their own hit tunes (Yano 2002: 35-36). The first instances of co-operation with record labels were concluded when, in the early 1930s, publishing companies realised that commissioning songs in newspapers would offer actually everybody the possibility of participating in musical propaganda. Songs that emerged in this way were called $k o ̄ b o k a$ 公募力 ('officially commissoned song'). The Asahi Shinbun 朝日新聞 cooperated with Columbia, the Mainichi Shinbun 毎日新聞 with Polydor and the $H \bar{o}$ chi Shinbun 報知新聞 with Victor (Sakuramoto 2005: 18-19). Furthermore, musical competitions were announced where participants had to write lyrics targeted to certain contents, with the music being composed afterwards. The winners received 
some prize money and several incentives (Kushner 2006: 31). According to Komota Nobuo 古茂田信男 et al., 'Manchurian march' ('Manshū-kōshinkyoku' 満州行進 曲, 1932) was one of the first kōboka. Another reason for commissioning songs was the shortage of entertainment during the war years. As the population in the countryside was even more affected than the urban population, the IRAA had theatre groups assembled to tour the back-country, which would not only perform plays written by themselves but also perform the prizewinning kōboka. Film companies such as Shōchiku 松竹 and Tōhō 東宝 took their share in these groups.

\section{Kōboka of the period $1937-1940$}

As one of the first and most representative examples of a kōboka I would like to name 'Patriotic march' ('Aikoku-kōshinkyoku' 愛国行進曲, 1937), which was commissioned at the end of the year 1937 by the government's information office. More than one million copies were sold. Sakuramoto lists $21 k \bar{b} b o k a$ for this period (Sakuramoto 2005: 20-21) — a figure that would grow as the war proceeded. Many of the songs have titles that do not give an exact idea of what the lyrics were about, e.g. 'Pacific march' ('Taiheiyō kōshinkyoku' 太平洋行進曲, 1939) or 'Daddy, you were strong' ('Chichi yo anata wa tsuyokatta’ 父よあなたは強かった, 1938), but most songs were about the happenings of that time: the invasion of China. The biggest sponsor of kōboka in those years was the Tōnichi 東日 publishing company, sponsoring seven songs.

\section{Kōboka of the period 1940 - November 1941}

During this period, more than twice as many kōboka released, in comparison to the earlier period reviewed; Sakuramoto lists 43 of them (Sakuramoto 2005: 35-37). From 1937 to 1939, political institutions had been involved in commissioning songs only on rare occasions, but now the Ministry of Defence sponsored as many songs as the Mainichi Shinbun (each of them seven). Interestingly enough, most of the song titles could give an idea of who the backer of the song was: 'Founded 2600 years ago'('Kigen nisen roppyakunen' 紀元二千六百 年, 1939) was sponsored by the Association on the Occasion of the Celebration of the 2600th Anniversary of the Jinmu-Tennō (Hōshuku-kai 奉祝会), 'Japanese work song' ('Nihon kinrō no uta' 日 本勤労の歌, 1940) by the Central Association for the Education of Workers (Kinrōsha-kyōiku-chūōkai 勤労者教育中央会), and 'Happy Manchuria' ('Tanoshii Manshū’ たのしい満州, 1940 or 1941) by the Manshü Shinbun 満州新聞 (Manchurian Newspaper). 
Kóboka of the period end of 1941 - April 1942

This short but very eventful period, when Pearl Harbor was attacked and Singapore conquered, evoked 13 songs (Sakuramoto 2005: 53-54). The institution sponsoring the highest number of songs was the IRAA, backing four kōboka, one of them, 'Asia's strength' ('Ajia no chikara'アジアの力, 1941 or 1942), in co-operation with NHK and the Greater Japanese Alliance for the Development of East Asia (Dai-Nihon Kyōa-Dōmei 大日本興亜同盟).

\section{Kōboka of the period May 1942 - 1945}

In this era, when Japan's luck turned during the Battle of Midway in June 1942 and Japanese defeat started to become apparent, 40 kōboka were released (Sakuramoto 2005: 56-57). NHK appeared as the biggest supporter with five songs, followed by Mainichi Shinbun and the IRAA (each of them with four songs).

See table 1 for the segmentation of sponsored/commissioned songs and their promoters.

\section{War incidents and their effect on radio programming}

By the late 1930s, about one decade after its introduction, radio had already broken the monopoly of newspapers as a mass medium. In keeping with NHK's slogan of 'one radio in each household', there were more than three million radio receivers by May 1937. Slogans like 'Defence by everybody, radios for everybody' were fixed to public buildings all over the country (Kasza 1988: 252 and NHK Broadcasting Culture Research Institute [NHK BCRI] 2002: 58). The economic upturn since 1936 allowed many families to buy a radio, and the growing number of radios in households made it easier to spread the Konoe Cabinet's guidelines for the formation of 'national morals' more efficiently.

The incident at the Marco Polo Bridge in the suburbs of Běijīng, which occurred during the night of 7 to 8 July 1937, was not reported until the early afternoon of 8 July. Why was that? The Ministry of Communication had forbidden the news to be broadcast before afternoon, a strategy that seems quite odd in terms of a launching war. In addition, news on the stationing of troops and similar topics that were subject to military strategies and could have influenced international relations, was prohibited. As the war proceeded, no names or mentioning of victims were announced on the radio to prevent a moral demotivation of the Japanese nation (NHK BCRI 2002: 56-57). In October 1937, the government started a national 'Week for Strengthening Mobilisation of the National Spirit' (Kokumin Seishin Sōdoîn Kyōchō Shūkan 国民精神総動員強調週間). Radio producers adapted the pro- 
gramme, playing songs like the national anthem 'Kimi ga yo' 君が代 and songs like 'When I go to sea' ('Umi yukaba'海行かば, 1937)—a ballad on the traditional warrior spirit.

After the conquest of Shànghăi in November 1937, Japanese troops moved forward to Nanjing, initially against the will of the Japanese government. But after the first achievements, the order to conquer Nanjing followed. Early on, Japanese newspapers and magazine spread an atmosphere of victory-but the real extent of the Nanjing Massacre was never a subject for the Japanese mass media, and a prohibition on talking about what they had done and seen was imposed on perpetrators and witnesses (Ishida 2003: 236). From 15 December 1937 until April 1938 Nanjing was 'sealed', and nobody was allowed to enter the city without an entourage of representatives of the Japanese embassy in Nanjing. On 20 December 1937, Dōmei announced that the residents of Nanjing were returning in their homes, though at that time the atrocities had not yet come to an end. Despite all efforts, the reality of what had occurred could not be kept secret from Germany and the US, though it was from the Japanese people. Yet specific clarification was not attempted until the tribunals in 1946 (Zöllner 2006: 366-367).

In November 1939, an agreement on state-operated controls regarding the radio channel allowed the Ministry of Communication to order certain contents of public and other interest to be broadcast and to take other measures if necessary (NHK: Nihon Hōsō Shi. Tōkyō: Nihon Hōsō Shuppan Kyōkai, 1965: 355; cited in Kasza 2002: 254).

In favour of marches for the army and the navy touching on the attack on Pearl Harbor on 8 December 1941, 'usual' pieces of music disappeared from NHK's radio programme. Songs played had titles like 'Militancy' ('Tōshi' 闘志, year unknown), 'Victory' ('Senshō' 戦勝, year unknown) and 'Cheer of triumph song' ('Kachidoki no uta' 勝鬥の歌, year unknown). From the day of the attack until April 1942, 27 new marches were composed, which were saturated with militarism (Sasaki 1976: 170). After the attack on Pearl Harbor, daily newscasts were expanded from six to 12 a day, and government and military announcements also increased. All news regarding the war was only allowed to be broadcast if licensed from the imperial headquarters (NHK BCRI 2002: 64-65). Apart from broadcasts on bushido 武士道 ('the way of the warrior'), the usual gymnastics programme and broadcasts for housewives, the radio programme for 8 December consisted of news and music (both live and recorded). Programmes in the following days were full of songs like 'March of the battleship' ('Gunkan-kōshinkyoku' 軍艦行進曲, 1910) and 'Destruction of the enemy’s character' ('Tekisei gekimetsu’ 適性撃滅, year unknown). From that time on, new songs were composed daily, and so-called news-songs (nyūsu kayō ニュース歌謡), written under pressure of time, were played after newscasts, sung by the radio choir accompanied by the Tōkyō Radio Symphony Orchestra, which had to be constantly on the alert (Takeyama 2005: 125; Sakuramoto 2005: 41-44). 
To name an example, 'The destruction of the British East Asia Fleet' ('Igirisu tōyō kantai kaimetsu’イギリス東洋艦隊壊滅, 1941) was composed on 10 December and aired only a few hours later at 8 p.m.- after headquarters had announced the scuttling of HMS Prince of Wales earlier that day at 4.20 p.m.

The attack on Pearl Harbor was followed by battles in Southeast Asia, the conquest of Hong Kong and Manila and the battle of Singapore, which turned out well for the Japanese, and radio programmes were created correspondingly.

Table 1 Overview of kōboka and their promoters from 1937 to 1945

\begin{tabular}{|c|c|c|c|c|c|}
\hline Institution & $\begin{array}{c}1937 \\
- \\
1939\end{array}$ & $\begin{array}{c}1940 \text { until } \\
\text { November } \\
1941\end{array}$ & $\begin{array}{c}\text { End of } \\
1941 \text { until } \\
\text { April } 1942\end{array}$ & $\begin{array}{c}\text { May } 1942 \\
\text { until Au- } \\
\text { gust } 1945\end{array}$ & $\begin{array}{c}\text { TOTAL } \\
(\%)\end{array}$ \\
\hline $\begin{array}{l}\text { Tōnichi Pub- } \\
\text { lishing Com- } \\
\text { pany }\end{array}$ & 7 & & & & $7(6.0 \%)$ \\
\hline $\begin{array}{l}\text { Mainichi Shin- } \\
\text { bun }\end{array}$ & & 7 & 2 & 4 & $13(11.1 \%)$ \\
\hline NHK & & 1 & & 5 & $6(5.1 \%)$ \\
\hline Asahi Shinbun & 3 & 3 & 1 & 2 & $9(7.7 \%)$ \\
\hline $\begin{array}{l}\text { Yomiuri Shin- } \\
\text { bun }^{5}\end{array}$ & 1 & 3 & 3 & 3 & $10(8.6 \%)$ \\
\hline $\begin{array}{l}\text { Main Depart- } \\
\text { ment of Army } \\
\text { Aviators }\end{array}$ & & & & 3 & $3(2.6 \%)$ \\
\hline IRAA & & 3 & $4^{6}$ & 4 & $11(9.4 \%)$ \\
\hline $\mathrm{CGJJ}^{7}$ & & & 1 & 2 & $3(2.6 \%)$ \\
\hline
\end{tabular}

5 読売新聞.

6 One of these songs was sponsored in co-operation with NHK and the Greater-Japanese Association for the Development of East Asia.

7 Community of Greater Japanese Young People. 


\begin{tabular}{|c|c|c|c|c|c|}
\hline Institution & $\begin{array}{c}1937 \\
- \\
1939\end{array}$ & $\begin{array}{l}1940 \text { until } \\
\text { November } \\
1941\end{array}$ & $\begin{array}{c}\text { End of } \\
1941 \text { until } \\
\text { April } 1942\end{array}$ & $\begin{array}{c}\text { May } 1942 \\
\text { until Au- } \\
\text { gust } 1945\end{array}$ & $\begin{array}{c}\text { TOTAL } \\
(\%)\end{array}$ \\
\hline $\begin{array}{l}\text { Railway De- } \\
\text { partment }\end{array}$ & & & & 2 & $2(1.7 \%)$ \\
\hline $\mathrm{CAJJ}^{8}$ & & & & 2 & $2(1.7 \%)$ \\
\hline $\begin{array}{l}\text { Broadcasting } \\
\text { Station Ōsaka }\end{array}$ & & 2 & & & $2(1.7 \%)$ \\
\hline $\begin{array}{l}\text { Navy Depart- } \\
\text { ment }\end{array}$ & $1^{9}$ & 2 & & & $3(2.6 \%)$ \\
\hline $\begin{array}{l}\text { Shufu no } \\
\text { tomo }\end{array}$ & 2 & 1 & & & $3(2.6 \%)$ \\
\hline $\begin{array}{l}\text { Army Depart- } \\
\text { ment }\end{array}$ & 2 & 7 & & & $9(7.7 \%)$ \\
\hline GJPIA $^{11}$ & & 1 & 1 & & $2(1.7 \%)$ \\
\hline $\begin{array}{l}\text { Greater- } \\
\text { Japanese Air- } \\
\text { line Company }\end{array}$ & & 1 & & 1 & $2(1.7 \%)$ \\
\hline $\mathrm{MAF}^{12}$ & & 1 & & 1 & $2(1.7 \%)$ \\
\hline $\begin{array}{l}\text { Miscellane- } \\
\text { ous }^{13}\end{array}$ & 5 & 11 & 1 & 11 & $28(23.9 \%)$ \\
\hline TOTAL & 21 & 43 & 13 & 40 & $117(100 \%)$ \\
\hline
\end{tabular}

8 Cultural Association of Japanese Young People.

9 In co-operation with Tōnichi Publishing Company.

10 主婦の友 Housewife's Friend magazine.

11 Greater Japanese Patriotic Industrial Assembly.

12 Ministry of Agriculture and Forestry.

13 Other institutions sponsoring only one song each. See footnotes in chapters 3.3.1. to 3.3.4. in Strasser 2007. 


\section{Popular songs as a mirror of their time}

Since singing is possible without a certain education and can be done anywhere, songs are a good medium to transport ideologies to less educated social classes and to circulate them quickly. One can shut one's eyes but not one's ears, and these are the reasons why popular music is one of the mightiest and most effective ideological appliances (Yano 2003: 159).

Differently from traditional folksong, popular song is music that catches an actual mood and 'preserves' it. Even if figures and images in popular song do not correspond exactly to reality, such a song is a representation of the feelings of the masses and also a pattern for what the masses should feel. Mita Munesuke 見田宗介 sees two possibilities for preserving the feelings of an era: letters, diaries and literary/journalistic contributions and reports; and popular arts - songs, theatre, literature and cinema. The latter are not produced by the people but for them, which means that artists and producers are the mediators who have to bring their forms of art in line with people's mentality (Mita 1992: 6). As distinct from cinema, theatre and literature, listeners of songs do not have to stay passive but can join in singing and pass the songs down over generations. Song lyrics reflect the mood of their author and singers and can depict a basic attitude towards 'public' ideology. Hence, prohibited and repressed songs between 1937 and 1945 spread relatively successfully; others were sponsored by official institutions and nevertheless were quickly forgotten. Even if songs mirror the feelings of individuals and the masses, they do not always correspond to all facets of reality as they stylise, glorify or just exaggerate. Good examples of exaggeration are songs that were confident of victory and which were still produced even when Japan's defeat was already clear. The titles of these songs displayed in part the complete opposite to the real situation.

Mita, a sociologist, has analysed popular songs from the period from the 1860s to the 1960s and found there are ten major divisions of feeling in Japanese popular song, which occur with different emphasis over time in contemporary songs: anger, tears, joy, love, chivalry, lingering attachment, jest, loneliness, nostalgia and yearning, and transience. Each of these feelings received diverse emphasis at different periods in song lyrics, permitting an interpretation of general contemporary circumstances. Mita issued a list of symbols in songs and their 'translations' (Mita 1992: 131-135), which I also used for my diploma thesis.

The gunka kayo 軍歌歌謡 (soldiers' songs, popular wartime songs) I discuss alongside the ryūkōka 流行歌 ('ordinary' popular songs) did not make their first appearance in the Second Sino-Japanese War, even if their form at that time was new. Komota Nobuo 古茂田信男 divides gunka with respect to gunka kayō into three phases: the origins of gunka kayō lie in the gunka of the First Sino-Japanese War (phase 1: 1894 to 1895) and the Russo-Japanese War (phase 2: 1904 to 1905). Phase 3 includes the years of the Second Sino-Japanese War (1937 to 1945, that is, 
the years ahead in the early 1930s. He divides the songs on the basis of the following features: songs from phases 1 and 2 were of a descriptive nature and had a defined picture of soldiers and their tasks, so-called katarimono 語り物 (literally 'a tale that is accompanied by music'). These old gunka were very dignified and intended for soldiers, not for civilians. This changed with the rising EuropeanAmerican influence towards the end of the Meiji Period (明治時代 1868 to 1912), when the expression of human feelings and a new openness became more important than lyric depictions (Komota et al 1981: 114-115). The new gunka kayō were meant for everybody, and the expression of feelings kept these songs from seeming too militaristic at first glance, which was of importance for their success in the third phase.

Besides the gunka kayō there were also successful ryūkōka. Their lyrics let their listeners assume the kind of imprints and thoughts the war had left in peoples' heads and hearts. In contrast to the gunka kayo promoted, their lyrics were often nostalgic and were not considered suitable for a radio programme at that time.

\section{Nationalism and the construction of 'home'}

\section{Nationalism and patriotism in Japan}

Brown names elements that are essential for the formation of nationalism, though not all of them might be given and premises can differ from nation to nation: geography, the belief in a common racial descent, common language, and common and unique religious beliefs (Brown 1955: 5-9). Since nationalism is often accompanied by economic expansion, it is easily accepted and evokes trust and pride. The more constant the above-mentioned elements the better. 'Soft' elements like social and economic conditions change more easily and are therefore not of the same importance for the rise of nationalism.

Nationalism is deployed to set borders in times when it is necessary to distance oneself from the 'outside'. This has not always happened in an aggressive way, but the term 'nationalism' has a negative connotation, most recently from the time of the Third Reich (Ohnuki-Tierney 2002: 249-250).

Further, nationalism is seen as a product of the modern age, developing from absolute monarchy. Bernhard Waldenfels names two kinds of nationalism: defensive and offensive nationalism (Waldenfels 1997: 151). He sees defensive nationalism as determined by resistance and 'closed' societies - which might be compared to Japan's external policy and self-chosen isolation during the time of sakoku 鎖国, when the country was closed to foreigners (from 1639 to 1858). The activities of the Japanese government since the Meiji Period-expansion, conquest and annexation- 
come within offensive nationalism. While defensive nationalism sees the world 'where there is home', offensive nationalism adopts foreign territories as its home.

The four elements Brown mentions as essential for the formation of nationalism were strongly marked in the Japan of the 1930s. Brown uses the term 'ultranationalism' to mark the peak of nationalism during the 1930s and 1940s. Benedict Anderson uses the phrase 'official nationalism', which describes an alliance of the new national and the old dynastic principle (Anderson 1988: 99-100, 139).

Another reason for the strong development of nationalism in Japan might have been the wish to distinguish Japanese from Chinese culture and not to surrender to Western influences. Japanese nationalism is a vivid example of the double function of the nation: protection for the people but also the demand for sacrifices.

Patriotism (aikokushin 愛国心) is an attitude that is expected from every citizen. It has the same roots as nationalism, but is known as its weakened version. The big difference generally lies in the attitudes of patriots and nationalists; whereas a patriot loves his home country, a nationalist devalues all other countries of the world. But nationalism was often concealed as patriotism, and which medium would have been a better promoter than the entertainment industry?

To turn historical discontinuity into what seemed a natural continuity, a process of 'naturalisation' took place. According to Emiko Ohnuki-Tierney: 'Nationalist and ethnic movements almost always involve constructions/inventions of the past of the people and the closing of the time between the past and the present so that the idealized past defines the essence of the people in the present. ...In Japan and elsewhere, we witness these processes of naturalization as the most powerful mechanism that national leaders used in their attempt to convert state nationalism into patriotism' (Ohnuki-Tierney 2002: 254). This practise is used when historic discontinuities have to be changed into continuities; naturalisation would then stand for something taken for granted, and cultural development would bear the impress of something naturally grown.

Eric Hobsbawm coined the concept of 'invented traditions'. Although this term may seem inappropriate at first, since in most people's understanding, traditions are something old that have grown naturally, in truth it is very unlikely that any society has never invented traditions. Hobsbawm divides invented traditions into three groups:

- traditions invented for the establishment or representation of social solidarity and a collective identity

- traditions developing certain institutions and social hierarchies and/or legitimising them

- traditions invented to put people in particular social contexts (Hobsbawm 183: 9) 
Ohnuki-Tierney points out that not all traditions which, following Hobsbawm, are thought to be invented traditions are in fact invented; some might have been just radically modified. She calls this 'refashioning of tradition' and moves on from Hobsbawm's idea.

The refashioning of tradition that happened in Japan in the 1930s refers to the proclamation of the eternity of the imperial system, in an attempt to blank out the centuries when there was no emperor in power. The aim of this refashioning process was to present the image of unconditional devotion to the emperor as an 'old' tradition. But to make a tradition 'tasty' it has to be aesthetically disguised. For this reason Japanese soldiers fighting in the Pacific War were symbolically equivalent to samurai and their 'honourable' dying was compared to withered cherry blossoms falling to earth (Ohnuki-Tierney 2002: 261). Hereafter I would like to explain how aesthetic configuration within the scope of naturalisation and refashioning of tradition works.

\section{Aesthetic configuration as a means of naturalisation}

Metaphors in popular wartime songs such as 'to fall like a beautiful cherry petal for the emperor' or promises to watch over the family as a deity in the Yasukuni Shrine 靖国神社 after one's own death, the depiction of Japanese women as flowers, etc., let us understand how dying, battle and the brutality of war were refashioned. I will explain more about the use of cherry blossom in terms of devotion to the emperor when the meaning of nature in Japanese popular song is discussed further on. Besides the image of dead soldiers as fallen petals of cherry blossom, the procedure of dying itself became aesthetically configured. This would also involve the configuration of dying as an act of honour, as a modern soldier falling in battle was put on a level with a samurai committing seppuku 切腹, an aesthetic not an auto-aggressive action.

\section{The concept of 'home' in wartime popular song}

During the war years, the notion of the 'mother country' (bokoku 母国) was replaced by that of 'land of the ancestors' (sokoku 祖国), referring to male ancestors. This meant that the image conveyed by a former female notion shifted to a masculinised conception of the state. Other terms used in that period were the 'imperial nation' ( $k \bar{o} k o k u$ 皇国) and the rarer 'nation of the Imperial Highness' (sumera miku$n i$ 天皇国) (Ohnuki-Tierney 2002: 151-152). Sometimes, in contemporary publications, 'land of the deities' (kami no kuni or shinkoku 神国), 'holy empire' (shinshū 神州) or just 'land' (kuni 国) were also used. 
Coming to the terms furusato and kokyō, both written with the same Chinese characters 故郷 (in the case of furusato the spellings 古郷 and 古里 are also common) or alternatively with the Hiragana spelling ふるさと, both furusato and kokyō are translated as 'Heimat' in German-language publications. In English publications, because of the lack of a word like 'Heimat', furusato is translated into 'hometown' or 'homeland', which does not entirely match the original meaning of both furusato and Heimat, since these two conceptions describe more of a feeling towards a place and its people than just a geographical site. Further, by singing about furusato and kokyō in songs on behalf of place names, everybody can refer to a place he or she has a strong relationship to. Furusato is not only the place where somebody was born and raised, but in times of globalisation and mobility is almost any place that somebody wants to call his home. A positive and strong feeling towards furusato is what both gunka kayō and ryūkōka have in common, with the difference that in ryūkōka homesickness and memories are important subjects, emerging during the Shōwa Period 昭和時代 (1926-1989) when young workers left their rural home villages to find work in the cities. The grief expressed in songs like 'Who is not longing for their home' ('Dare ka kokyō o omowazaru', 誰か故郷を思わざる, 1940) is an example of 'ordinary' homesickness, of being separated from one's family for more or less voluntary reasons, not by war, and with an option to come back home.

Hans-Joachim Busch explains Heimat as a phenomenon of interaction, not just a fixed geographical place, but a place that is associated with people and feelings, 'associated with affectively tinted interpersonal relationships' (Busch 1995: 83). In lyrics and poetry such interaction is often confirmed by the frequent mentioning of mother, brothers and sisters, and school friends. Heimat/furusato is often used on behalf of 'nation', probably because it sounds more comfortable and familiar than nation. Christine Yano notices an ambiguous attribution to furusato: furusato as a place where one has his/her family and origins, and furusato as a description for the mythic Japan (Yano 2002: 18). In keeping with the latter attribution, all Japanese are one family, which finds expression in phrases in songs like wareware nihonjin 我々 日本人 ('We Japanese'). I would now like to discuss two elements in the concept of Heimat in Japanese popular song.

The Tennō in wartime Japanese popular song: a father or a mother figure?

Earlier I explained the Tennō's role in state Shintō; now I would like to explain his symbolic meaning for the Japanese people in wartime songs. In contrast to Hitler and Mussolini, Hirohito 裕仁 (the Shōwa Tennō) clearly had no personality as a 'Führer'. His term of office outlasted the war, and even when the state and Shintō were separated after the war, he never had to justify himself in front of a tribunal. In 
1989, only a quarter of participants in a survey of people's opinions about the Tennō's war responsibility took the view that the Tennō should have taken over political responsibility for Japan's role in WWII (Schwentker 2003: 124).

Since 1905, the image of Japanese families as branches of the imperial family had been widespread in schoolbooks. According to Confucian teaching, moral loyalty towards one's parents and filial piety were the highest virtues. The traditional family structure was seen as a model for a strong state ideology, and for the social ethos bushidō served as an example. But as the war proceeded, with fathers conscripted, not only vertical but also lateral family relations grew strong (Bellah 2003: 177-178). Women were not as weak and marginal as they were often portrayed, on the contrary, we can assume that women were mostly the centre of the family while the father played - emotionally - a smaller part. How can we link this to the Tennō, who-in wartime songs - symbolises motherliness?

Robert N. Bellah sees the answer to that question in Japan's mythology. The sun goddess Amaterasu 天照神 is the most important character in Japanese mythology and is seen as the Tennō's direct ancestor. Through Amaterasu the Japanese emperor must be understood as the centre of a strict, Confucian family state cult (Bellah 2003: 178). Amaterasu is often displayed as a weak personality, who frequently relies on other deities when it comes to making decisions. She is more often represented as a peacemaker than as a despot. Like a mother in her family, the Tennō is at the centre of the state emotionally, but is without actual power, more like a secret head and the first shelter. The Tennō's counterpart - the father figure-was represented by the commanding shōgun and later politicians, who were aggressive, strong men like Oda Nobunaga 織田信長, Yamagata Aritomo 山県有朋 or Tōjō Hideki 東 条英機, men that were looked up to but hardly 'loved' by the masses. The Tennō's 'humanisation' after the war has probably contributed to seeing the Tennō as the opposite of 'male authority'.

Looked at in that way, one can say that the mother builds the internal base in the branch family and the Tennō the external base in the state. Seen from the Confucian point of view regarding loyalty towards one's parents, 'dying for the emperor involves not just an abstract moral duty but a warm personal relation. Not only will I die for the emperor but the emperor will worship me' (Bellah 2003: 181). These circumstances made dying for the emperor not only a moral obligation but created a personal relationship with him. The family cult has shifted to the emperor cult, a procedure that is presumably unique in East Asia (Bellah 2003: 176-183). As a sign of success and a desirable goal, 'arriving' at the Yasukuni Shrine was equal to receiving motherly love. 


\section{Images and meanings of nature}

All along the Japanese people have been said to have a peculiar love of nature, which is a rich source of metaphors and symbols in Japanese lyric poetry. However, when looking at how nature is dealt with in ecological terms, in the Japanese perception nature seems to be something that needs to be 'tamed'. Asking what nature, war and wartime song may have in common, since they do not seem to be points of contact at first glance, I would like to turn to the depiction of furusato, and its nature, which now seem to make more sense. However, nature cannot be just used and read as a description of furusato and its surroundings, but as a metaphor for feelings or as signs of aesthetic configuration. I would like to explain this in more detail with the aid of the sea and cherry blossom.

For a symbol to have impact, the audience must have a minimal common grasp of what should be expressed. Symbols and metaphors in Japanese lyric poetry are conventional and established, they are common property, and mention of them indicates certain situations, feelings and seasons (compare the haiku 俳句 and the use of kigo 季語 to give an idea about the season described in the haiku), whereby one symbol can have several attributions (compare Schönbein 2001: 12). Reading lyrics and knowing about the meanings of metaphors, we realise that lyrics are not about nature in the first place but express feelings, using nature's manifestations as a pool for metaphors.

\section{The sea}

The sea plays a large role in Japanese song lyrics, be it as a metaphor for feelings or as an expression of a distance that has to be conquered to beat the enemy. According to Sepp Linhart (Linhart 2003: 525) 18.6 percent of popular songs in the period from 1941 to 1945 bear upon the sea, a percentage never again as high as in those years. Regarding emotional metaphors, the sea is not expressly mentioned, but words associated with the sea are. Comparing the symbols associated with the sea with Mita's list of emotional symbols, e.g. foam, bubbles and waves (for transience), harbour (nostalgia, hope, exoticism) or seagulls (volatility) one can see that these symbols represent somewhat sentimental meanings (Mita 1992: 131-135). Only when expressing expansion is the sea viewed in a positive way. This means that the sea is used as a hopeful symbol in $k o ̄ b o k a$, which were meant to spread a positive, confident atmosphere, rather than in the usual ryūkōka. In 'Japan going to the sea' (1942, 'Umi yuku Nippon' 海行く日本, 1942), cruising on the sea equates to an expanding Japan, and the Japanese are pictured as a 'people of the sea, with waves as pillows and the tempest as a song' (nami o makura ni arashi o uta ni 波を枕に嵐 を歌に). 
Though no furusato is actually mentioned, I have chosen to analyse this song for my work, because the expansion of Japan as a home is a subject in here. The commissioning for this song asked for a song on the 'conquest of the seven oceans' (shichiyō seiha no uta 七洋制覇の歌) (Shimura 2005: 358). At that time Japanese territory stretched from the Aleutians in the north to the Solomon Islands in the south. In this song, militancy and the sea are connected in a favourable way, the sea as travelway is linked with 'eternal luck' and 'beneficial winds', the battleships are the symbol for power and the Kuroshio's warm stream contributes to success, while in nostalgic songs of that time the sea always signified sadness (farewell, separation, etc.), as in 'Farewell Blues' ('Wakare no burūsu’別れのブルース, 1937).

\section{Cherry blossom}

In Japanese lyrics, cherry blossom holds an exceptional position among all flowers; in classical Japanese poetry, as a kigo it signifies springtime. Martina Schönbein lists 45 forms of sakura 桜 (cherry, cherry blossom) that are used in Japanese poetry as a motif for seasons (Schönbein 2001: 94-98), among them rakka 落花, the falling cherry blossom. My question is, if cherry blossoms stand mostly for spring and awakening, what do they actually indicate in wartime popular song? Why are they associated with kamikaze pilots 神風 and the Yasukuni Shrine?

In wartime songs, cherry blossoms signify transience caused not by natural means but by war incidents. All other flowers mentioned in Japanese wartime songs represent women - a good example is the song 'Patriotic flowers' ('Aikoku no hana' 愛国の花, 1938) — and cherry blossoms are the only flowers that symbolise manhood, to be more specific, deceased Japanese soldiers. A descending cherry blossom would symbolise a kamikaze pilot falling from the sky.

In contrast to Christianity, in Shintōism, Confucianism and Buddhism, there is no belief in an almighty god and a life after death, hence no entry to heaven. A construction for the commemoration of fallen soldiers was needed, but since the bodies of deceased soldiers were not available in their home country of Japan, a prerequisite for a proper funeral, the concept of cherry trees in bloom in front of the Yasukuni Shrine representing all fallen soldiers was introduced. ${ }^{14}$ The understanding that they would return as cherry blossom was often built into songs, a well-known example being 'Cherry blossoms of the same age group' ('Dōki no sakura' 同期の桜, $1938 / 1944^{15}$ ), in which the singer names the Yasukuni Shrine as his last home and thus a place to meet his friends from aviation school. In 'Mengjiang tune' ('Mōkyōbushi' 蒙疆ぶし, 1938), the protagonist seems to be quite serene when telling

14 Here we can observe a 'refashioning of tradition'.

15 According to Shimura (2005: 409) the song had been composed in 1938 but only gained popularity after some lyrical adaption in 1944. 
those he has left bereaved to come to the Yasukuni Shrine at the time of the cherry blossom to see him again. In 'Mother of our homecountry'('Mikuni no haha' 皇国 の母, 1938), the line 'the day of our next meeting will be in April next year-under the blossoms of the Yasukuni Shrine' (kondo au no hi wa rainen shigatsu Yasukuni jinja no hana no shita 今度会うの日は来年四月靖国神社の花の下) obtains a specific meaning. At first, one might think that this line is about a face-to-face meeting of mother and son. But a second reading reveals what lies between the lines and becomes visible only when one understands the dimension of the metaphors used in Japanese song lyrics.

Cherry blossom is to be understood as a symbol for brave manhood and all its consequences, and is often mentioned in combination with the Yasukuni Shrine as a 'terminal', while other flowers, including the 'modest' form of the wild cherry (yamazakura 山桜), as it is sung about in 'Aikoku no hana', stands for the female principle: endurance, courage and tenacity at the home front.

\section{Conclusion}

As with the question of the Tennō's war responsibility, we must also ask about the responsibility of artists and music producers in supporting state propaganda. Yamada Kōsaku 山田耕筰, the founder of Japan's first symphony orchestra, who contributed innumerable songs to Japanese popular music, remarked: 'Why would any one of us have to take responsibility although the Tennō is not taking his responsibility?' (Tennō ga sekinin o taranai no ni, dōshite wareware ga sekinin o toru hitsuyō ga aru no ka? 天皇が責任をとらないのに、どうして我々が責任をとる 必要があるのか) (Sasaki 1976: 182). With a Tennō who did not resign, it would have been hard to officially conduct self-reflection after the war. Yamada's question might seem reasonable, but it does not satisfy. Furthermore, an act of evasion was deployed: deception. The director Itami Mansaku spoke his mind about such 'deception' and names deception as a consequence of a lack of knowledge and a weak volition - and therefore being beguiled and absolved from responsibility as a crime (Sasaki 1976: 183). Honest self-reflection would have needed the courage to confess to a lack of will to show opposition. Of course, neither must NHK's guilt as a distributor of propaganda be overlooked.

Turning back to wartime popular songs and their construction of home, we can say that they-both kōboka and the usual ryūkōka-have one big thing in common: longing. Be it the desire for victory, the hometown, the mother or just better times: all songs have a desire for a change of the current state in their lyrics. In köboka it is about expanding and going forward, in nostalgic ry $\bar{u} k \bar{o} k a$ it is about returning to something or somebody or a certain time in life (e.g. school days). When nostalgia and longing for home first appeared in ryūkōka during the interwar period, they were 
probably an outlet for the daily struggle. Looking at these nostalgic songs, which offered a forum for the sentimental feelings of the masses apart from any propaganda, we may also think about their construction of home. Are their lyrics always authentic, just because they were not a state-supported means of propaganda? If an authentic depiction of 'home' is not to be found in köboka lyrics, are its elements then to be found in nostalgic songs? Can we apply the refashioning/invention of traditions only to the mythological constructs of the gunka kayo or also to the simpleness in nostalgic songs? Yano points out that 'the amnestic quality of nostalgia continually surprises. It selects which details to obscure in order to naturalize memory, history, and identity and then build its own phantasmic utopia' (Yano 2002: 17). Yano sees memory as a substance of identity, and so there is - once again - the question of the construction of home, which is the cradle of identity. Yes, at first sight, in kōboka home is a constructed thing, but can we assume, without asking about the concept of home in ry $\bar{u} k \bar{o} k a$, that $r y \bar{u} k \bar{o} k a$ are about the reality of home? Both genres share significant elements:

- tranquillity and a calm life in one's native home, which is surrounded by rustic scenery: mountains, lakes and fields

- childhood is something remembered with pleasure

- a good relationship with one's mother

In addition, both genres avoid any description of the cruelties of daily life - at the home front or on the battlefield. The difference lies in the mood the songs transfer; while gunka kayō always have a sense of a 'Heave-ho' mood, even when in reality the prospects were bad, nostalgic songs transfer a quite passive and sad mood. We must also consider that the above-mentioned elements cannot always be understood as fully authentic, whether in gunka kayo nor in ryūkōka: not all Japanese were raised in the countryside by a loving mother and would have preferred living in a rural village to life in a big city with all its modern amenities and facilities for entertainment.

After immersing myself in this topic of propaganda and constructions of home through song lyrics, I would also like to mention that, in watching the contemporary handling of Japanese wartime songs, we can notice that obviously there is still a lot of self-reflection to be done. Most sources I found on the Internet were completely non-critical towards propagandistic songs, and there exist hardly any monographs that deal specifically with this subject. Compilations of gunka kayō can be bought from online traders and idealising websites offer plenty of information on wartime songs (which is good for the researcher, but bad for the image of the website holder).

The field of entertainment music and its history and abuse during war may seem less important than other topics that have to be discussed regarding Japanese war history. But 'light' music can convey heavy contents, and in regard to Japanese war 
propaganda it should be not underestimated, but seen as a small stone in the greater mosaic of Japan's history. 


\section{REFERENCES}

Anderson, Benedict. Die Erfindung der Nation. Zur Karriere eines erfolgreichen Konzepts. transl. Benedikt Burkard. Frankfurt and New York: Campus Verlag, 1988

Balfour, Michael. Propaganda in War: 1939-1945. Organisations, Policies and Publics in Britain and Germany. London, Boston and Henley: Routledge and Kegan Paul, 1979

Bellah, Robert N. Imagining Japan. The Japanese Tradition and its Modern Interpretation. Berkeley, Los Angeles and London: University of California Press, 2003

Brown, Delmer M. Nationalism in Japan. An Introductory Historical Analysis. New York: Russell \& Russell, 1955

Buchbender, Ortwin, and Horst Schuh. Die Waffe, die auf die Seele zielt. Psychologische Kriegsführung 1939 - 1945. Stuttgart: Motorbuch Verlag, 1983

Busch, Hans-Joachim "Heimat als Resultat von Sozialisation - Versuch einer nicht-ideologischen Bestimmung." In Wem gehört die Heimat? Beiträge der politischen Psychologie zu einem umstrittenen Phänom, edited by Wilfried Belschner, Siegfried Grubitzsch, Christian Leszczynsi, Stefan Müller-Doohm. Opladen: Leske und Budrich, 1995, pp. 81-86

Choki, Seiji. "Manfred Gurlitt in Japan. Zum Symposion 'Das Musiktheater in Exil und Diktatur und seine Rezeption'.” http://www.asahi-net.or.jp/ ib4s-Cyuk/gurlitt_in_japan.pdf, accessed April 2006

Daniels, Gordon. "Japanese Broadcasting in the Pacific War." In Shōwa Japan. Political, Economic and Social History. 1926-1989. Volume II, 1941-1952, edited by Stephen S. Large. London and New York: Routledge, 1998, pp. 272-279

Hall, John Whitney. Das japanische Kaiserreich. transl. by Ingrid Schuster. Frankfurt am Main: Fischer Taschenbuch Verlag (= Fischer Weltgeschichte 20), 1968

Hobsbawm, Eric J. “Introduction: Inventing Tradition.” In The Invention of Tradition, edited by Eric J. Hobsbawm and Terence Ranger. Cambridge: Cambridge University Press, 1983, pp. 114

Ishida, Yuji. "Das Massaker von Nanking und die japanische Öffentlichkeit.” In Erinnerungskulturen. Deutschland, Italien und Japan seit 1945, edited by Christoph Cornelißen, Lutz Klinkhammer and Wolfgang Schwentker Frankfurt am Main: Fischer Taschenbuch Verlag, 2003, pp. 233-242

Kasza, Gregory J. The State and the Mass Media in Japan, 1918-1945. Berkeley and Los Angeles: University of California Press, 1988

Kitagawa, Kenzō 北河賢三. Kokumin no sōdōin no jidai 国民の総動員の時代 [The age of general mobilisation of the nation]. Tōkyō: Iwanami Shoten, 1989

Komota, Nobuo 古茂田信男. Yoshifumi Shimada 芳文島田, Tamotsu Yazawa 保矢沢 and Chiaki Yokozawa 千秋横沢. Nihon ryūkōka-shi. Senzen-hen 日本流行歌史。戦前編 [History of Japanese popular song. Prewar period]. Tōkyō: Shakai shisōsha, 1981

Kushner, Barak. The Thought War. Japanese Imperial Propaganda. Honolulu: University of Hawai'i Press, 2006

Linden, Marcel van der and Gottfried Mergner. "Kriegsbegeisterung und mentale Kriegsvorbereitung" In Kriegsbegeisterung und mentale Kriegsvorbereitung. Interdisziplinäre Studien, edited by Marcel van der Linden and Gottfried Mergner. Berlin: Duncker und Humblot (Beiträge zur Politischen Wissenschaft, Volume 61), 1991, pp. 9-27

Linhart, Sepp. "Das Meer im deutschen und im japanischen Schlager." In Sonderdruck der Zeitschrift der Schweizerischen Asiengesellschaft 'Meer und Berge in der japanischen Kultur. Europäische Japan-Diskurse III und IV', edited by Eduard Klopfenstein and Simone Müller (Asiatische Studien LVII, 3, 2003), 2003, pp. 515-544 
Lokowandt, Ernst. "Einleitung." In Zum Verhältnis von Staat und Shintō im heutigen Japan. Eine Materialsammlung, edited by Ernst Lokowandt. Wiesbaden: Otto Harassowitz, 1981, pp. 1-24

Mita, Munesuke. Social Psychology of Modern Japan. transl. by Stephen Suloway. London and New York: Kegan Paul International, 1992

NHK Broadcasting Culture Research Institute (NHK BCRI). Broadcasting in Japan. The Twentieth Century Journey from Radio to Multimedia. Tōkyō: NHK, 2002

Ohnuki-Tierney, Emiko. Kamikaze, Cherry Blossoms, and Nationalisms. The Militarization of Aesthetics in Japanese History. Chicago and London: University of Chicago Press, 2002

Sakuramoto, Tomio. 櫻本富雄. Uta to sensō. Minna ga gunka wo utatteita 歌と戦争。みんなが 軍歌をうたっていった [Song and war. Everybody was singing soldiers' songs]. Tōkyō: Atene shobō, 2005

Sasaki, Akira. 佐々木光. “Ongakka to sensō sekinin - senjika no shomondai” 音楽家と戦争責任 一戦時下の諸問題 [Musicians and war responsibility - various problems in times of war]. Nihon Ongaku buyō kaigi 日本音楽舞踊会議 [Conference on Japanese Music and Dance] Kindai nihon to ongaku. 近代日本と音楽 [Modern Japan and music.] Tōkyō: Ayumi Shuppan, 1976, pp. 163-185

Schönbein, Martina. Jahreszeitenmotive in der japanischen Lyrik. Zur Kanonisierung der kidai in der formativen Phase des haikai im 17. Jahrhundert. Wiesbaden: Harrassowitz (BUNKEN. Studien und Materialien zur japanischen Literatur, 6), 2001

Schwentker, Wolfgang. "Die Grenzen der Entzauberung. Zur Rolle des Tenno in Staat und Gesellschaft Japans nach 1945.” In Erinnerungskulturen. Deutschland, Italien und Japan seit 1945, edited by Christoph Cornelißen, Lutz Klinkhammer and Wolfgang Schwentker. Frankfurt am Main: Fischer Taschenbuch Verlag, 2003, pp. 123-136

Shillony, Ben-Ami. Politics and Culture in Wartime Japan. Oxford: Clarendon Press, 1981

Shimura, Fumio 志村文世. Nihon no uta. Dai 2 shü. Shōwa (ichi) sho kara 20nen (4satsu hakkō) 日本のうた。第 2 集。昭和 (一) 初一 20 年。 4 刷発行 [Songs of Japan. Volume 2. Shōwa 1 to Shōwa 20, 4th edition]. Tōkyō: Nobarasha [First Edition 1998], 2005

Strasser, Sabiene. “'Wer sehnt sich nicht nach der Heimat?' - Heimat, Militarismus und Nostalgie im japanischen Schlager von 1937 bis 1945.” Diploma thesis, University of Vienna, 2007

Takeyama, Akiko 竹山昭子. Shiryō ga kataru taiheiyō sensō-ka no hōsō 史料が語る太平洋戦争 下の放送 [Broadcasting during the Pacific War, told by means of historical sources.] Kyōto: Sekai shishōsha, 2005

Tipton, Elise K. Modern Japan. A Social and Political History. London and New York: Routledge, 2002

Waldenfels, Bernhard. Topographie des Fremden. Frankfurt am Main: Suhrkamp (Studien zur Phänomenologie des Fremden I), 1997

Yano, Christine R. Tears of Longing. Nostalgia and the Nation in Japanese Popular Song. Cambridge and London: Harvard University Press, 2002

Yano, Christine R. "Distant Homelands. Nation as a Place in Japanese Popular Song." In Consuming Ethnicity and Nationalism. Asian Experiences, edited by Yoshina Kosaku. Richmond, UK: Curzon Press, 2003, pp. 158-176

Zöllner, Reinhard. Geschichte Japans. Von 1800 bis zur Gegenwart. Paderborn: Ferdinand Schöningh, 2006 


\section{GLOSSARY}

\begin{tabular}{|c|c|}
\hline 'Aikoku-kōshinkyoku' & 愛国行進曲 \\
\hline 'Aikoku no hana' & 愛国の花 \\
\hline aikokushin & 愛国心 \\
\hline 'Ajia no chikara' & アジアの力 \\
\hline Asahi Shinbun & 朝日新聞 \\
\hline bokoku & 母国 \\
\hline bōshi yōchō & 暴支膺懲 \\
\hline bushi & 武士 \\
\hline bushidō & 武士道 \\
\hline $\begin{array}{l}\text { 'Chichi yo anata wa tsuyo- } \\
\text { katta' }\end{array}$ & 父よあなたは強かった \\
\hline Dai-Nihon Kyōa-Dōmei & 大日本興覀同盟 \\
\hline Dentsū & 電通 \\
\hline 'Dōki no sakura' & 同期の桜 \\
\hline Dōmei Tsūshinsha & 同盟通信社 \\
\hline enka & 演歌 \\
\hline furusato & 古郷 \\
\hline gunka & 軍か \\
\hline gunka kayō & 軍歌謡 \\
\hline 'Gunkan kōshinkyoku' & 軍艦行進曲 \\
\hline gunkoku kayō & 軍国歌謡 \\
\hline guntai zokuyō & 軍隊俗謡 \\
\hline haiku & 俳句 \\
\hline heitai bushi & 兵隊武士 ～～～～～～～ \\
\hline 'Heitaisan yo arigatō' & 兵隊さんよありがとう \\
\hline Hōshuku-kai & 奉祝会 \\
\hline
\end{tabular}

'Igirisu tōyō kantai kaimetsu'
'March of patriotism' (song, 1937)

'Patriotic flowers' (song, 1938) patriotism

'Asia's strength' (song, 1941/42)

Asahi Newspaper; Japan's biggest newspaper mother country violent castigation of China warrior the way of the warrior, code of honour for samurai

'Daddy, you were strong' (song, 1938)

Greater Japanese Alliance for the Development of East Asia press agency

'Cherry blossoms of the same age group'

Dōmei Press Agency; founded 1935 by the Ministry of Foreign Affairs and Communication nostalgic, folksy pop song home, literally 'old village', 'Heimat' soldiers' song, war song soldiers' popular song, popular war song

'March of the battleship' (song, 1910) military (state) song army folksong haiku, Japanese poetry soldiers' tune

'Thank you, Mr Soldier' (song, 1939)

Association for Celebrations, short form for Association for the Occasion of the Celebration of the 2600th Anniversary of the Jinmu-Tennō 'The destruction of the British East Asia Fleet' (song, 1941) 


\begin{tabular}{|c|c|}
\hline jinchū hōkoku & 尽忠報国 \\
\hline Jōhō-kyoku & 情報局 \\
\hline 'Kachidoki no uta' & 勝鬨の歌 \\
\hline kami & 神 \\
\hline kamikaze & 神風 \\
\hline katarimono & 語り物 \\
\hline kayōkyoku & 歌謡曲 \\
\hline kennin jikyū & 賢忍持久 \\
\hline 'Kigen nisen roppyakunen' & 紀元二千六百年 \\
\hline kigo & 季語 \\
\hline 'Kimi ga yo' & 君が代 \\
\hline 'Kinrō no uta' & 勤労の歌 \\
\hline Kin-rōsha kyōiku-chūōkai & 勤労者教育中央会 \\
\hline kōboka & 公募歌 \\
\hline ‘Kōhan no yado' & 湖畔の宿 \\
\hline kokka shintō & 国家神道 \\
\hline Kokka sōdōin hō & 国家総動員法 \\
\hline ‘Kokkyō no machi’' & 国境の町 \\
\hline kōkoku & 皇国 \\
\hline Kokumin Gasshō & 国民合唱 \\
\hline kokumin no sen'i kōyō & 国民の戦意高揚 \\
\hline kokumin ongaku & 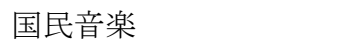 \\
\hline $\begin{array}{l}\text { Kokumin seishin sōdōin } \\
\text { chūōrenmei }\end{array}$ & 国民精神総動員中央連盟 \\
\hline $\begin{array}{l}\text { Kokumin seishin sōdōin } \\
\text { kyōchō shūkan }\end{array}$ & 国民精神総動員強調週間 \\
\hline kokuminkayō & 国民歌謡 \\
\hline Kokutai no hongi & 国体の本義 \\
\hline kokyō & 故郷 \\
\hline Komota Nobuo & 古茂田信男 \\
\hline Konoe Fumimaro & 近衞 文麿 \\
\hline koto & 琴 \\
\hline kyokoku itchi & 挙国一致 \\
\hline Manshū Shinbun & 満州新聞 \\
\hline
\end{tabular}

serve the home country faithfully

Press and Information Agency 'Cheer of triumph song' (song, year unknown)

deities

kamikaze, suicide pilots in WWII (literally 'divine wind') tale popular song, hit song the slogan of 'persistent perseverance'

'Founded 2600 years ago' (song, 1939) word symbolising a season in Japanese poetry Japan's National Anthem 'Japanese work song' (song, 1940)

Association for the Education of Workers commissioned song 'Shelter by the lakefront' (song, 1940)

State Shintō; non-religious state ideology

National Law of General

Mobilisation

'Border town' (song, 1934) imperial nation folk choir increase of national fighting spirit national music

Central Alliance for the Mental Mobilisation of the People Week for Strengthening Mobilisation of the National Spirit folksong Principles of the Body Politic home

Komota Nobuo; author (see reference list)

Konoe Fumimaro (prime minister, *1891-1945)

Japanese harp national entity Manchurian Newspaper 
'Manshū-kōshinkyoku'

Meiji jidai

'Mikuni no haha'

Mita Munesuke

'Mōkyōbushi'

naikaku jōhō-bu

Nihon hōsō kyōkai

Nihon kokuminka undō

Nihon Ongaku Bunka Kyōkai

ninteki shigen

nyūsu kayō

Oda Nobunaga

$\begin{array}{ll}\text { onban } & \text { 音盤 } \\ \text { rakka } & \text { 落花 } \\ \text { rekōdo } & \text { レコード } \\ \text { Rengō } & \text { 連合 } \\ \text { ryūkōka } & \text { 流行歌 } \\ \text { sakoku } & \text { 鎖国 } \\ \text { sakura } & \text { 桜 } \\ \text { Sakuramoto Tomio } & \text { 桜本富雄 } \\ \text { seishin sōdōin } & \\ \text { senji kayō } & \text { 精神総動員 } \\ \text { 'Senshō' } & \text { 戦時歌謡 } \\ \text { seppuku } & \text { 戦勝 } \\ \text { shakuhachi } & \\ \text { shamisen } & \text { 切腹 } \\ \text { shinkoku } & \text { 尺八 } \\ \text { shinshū } & \text { 三味線 } \\ \text { Shintaisei } & \text { 神国 } \\ \text { shisōsen } & \text { 神州 } \\ \text { Shōchiku } & \text { 新体制 } \\ \text { Shōwa jidai } & \text { 思想戦 } \\ \text { Shufu no tomo } & \text { 松竹株式会社 } \\ & \\ & \text { 昭和時代 } \\ & \text { 主婦の友 }\end{array}$

満州行進曲

明治時代

皇国の母

見田宗介

蒙疆ぶし

内閣情報部

日本音楽文化協会

日本国民歌運動

日本音楽文化協会

人的資源

ニュース歌謡

織田信長

主婦の友
'Manchurian march' (song, 1932)

Meiji Period (1868-1912)

'Mother of our home country' (song, 1938)

Mita Munesuke (sociologist, author, *1937, see reference list)

'Mengjiang tune' (song, 1938) cabinet information office NHK, Japanese Broadcasting Corporation, founded 1926 campaign for 'Japanese folksongs'

The Cultural Union for Japanese Music *1941

human resources

'news song'

Oda Nobunaga (iniator of Japan's unification, *15341582)

'sound disc'

falling cherry blossom record press agency popular song, hit song, nostalgic song

Japan's self-imposed isolation (1639-1858)

cherry blossom

Sakuramoto Tomio; author (see reference list) mental mobilisation wartime popular song 'Victory' (song, year unknown)

ritual suicide

Japanese flute

Japanese string instrument land of deities

holy empire

New National Organisation ideological war(fare)

Shōchiku Kabushiki-kaisha, film company, founded 1895 Shōwa Period (1926-1989) 'Housewife's Friend' Magazine 
sokoku

sumera mikuni

'Taiheiyō- kōshinkyoku'

Taisei yokusan undō

'Tanoshii Manshū'

'Taue'

'Tekisei gekimetsu'

tekisei ongaku

Tōhō

Tōjō Hideki

Tōnichi

'Tōshi'

'Umi yukaba'

'Umi yuku nihon'

'Wakare no burūsu' wareware nihonjin

Yamada Kōsaku

Yamagata Aritomo

yamazakura

Yasukuni Shrine

Yomiuri Shinbun
祖国

天皇国

太平洋行進曲

体勢翼賛運動

たのしい満州

田植

適性撃滅

適性音楽

東宝株式会社

東條 英機

東日

闘志

海行かば

海行く日本

別れのブルース

我々日本人

山田 耕筰

山県有朋

山桜

靖国神社

読売新聞 land of the ancestor

land of the imperial highness

'Pacific march' (song, 1939)

Imperial Rule Assistance

Association

'Happy Manchuria' (song, 1940/41)

'Rice plantling' (song, 1942)

'Destruction of the enemy character' (song, year unknown)

enemy music

Tōhō Kabushiki-kaisha, film company, founded 1932

Tōjō Hideki (general of the Japanese Army and prime minister, *1884-1948)

Tōnichi Publishing Company

'Militancy' (song, year un-

known)

'When I go to sea' (song, 1937)

'Japan going to sea' (song, 1942)

'Farewell blues' (song, 1937)

'we Japanese'

Yamada Kōsaku (composer and conductor, founder of the first Japanese Symphony

Orchestra, *1886-1965)

Yamagata Aritomo (field marshall, 'father' of Japanese militarism, *1838-1922)

wild cherry

Yasukuni Shrine in Tōkyō, dedicated to fallen Japanese soldiers

Yomiuri Newspaper 